УДК 372.881.111.1

DOI https://doi.org/10.26661/2522-4360-2021-2-24

\title{
СУТНІСТЬ І СПЕЦИФІКА ІНШОМОВНОЇ КОМПЕТЕНТНОСТІ МАЙБУТНІХ ФАХІВЦІВ ІЗ НАВІГАЦІЇ Й УПРАВЛІННЯ МОРСЬКИМИ СУДНАМИ
}

\author{
Швецова I. В. \\ кандидат педагогічних наук,дочент кафедри англійської мови у судноводінні \\ Херсонська державна морська академія \\ вул. Ушакова, 20, Херсон, Україна \\ orcid.org/0000-0002-6801-5204 \\ isvecova581@gmail.com
}

\begin{abstract}
Ключові слова: іншомовна освіта, професійна підготовка майбутніх фахівців із навігачіï й управління морськими суднами, професійна готовність майбутніх фахівців, ичіннісне відношення до іноземної мови.
\end{abstract}

У статті розглядається сутність та специфіка іншомовної компетенції майбутніх фахівців 3 навігації та управління суднами. Проведено аналіз останніх публікацій із цього питання та виявлено особливості іншомовної компетентності майбутніх фахівців. Визначено, що оволодіння і використання іноземної мови в закладах вищої освіти полягає у формуванні іншомовної компетентності, яка забезпечує здатність до застосування предметних, наукових знань, засобів i діяльності у професійному спілкуванні, що дозволяє підвищити загальну компетентність та сприяє формуванню психологічної готовності до специфіки професійної діяльності. Для аналізу теоретичних і методичних основ формування іншомовної компетентності майбутніх фахівців із навігації й управління морськими суднами та на основі аналізу результатів наукових досліджень охарактеризовано використання понять дослідження: «компетентність», «іншомовна компетентність», «професійна готовність майбутніх фахівців».

На основі сучасних педагогічних підходів та напрямків, які було проаналізовано в дослідженні, визначено компоненти іншомовної компетентності майбутніх фахівців із навігації і управління морськими суднами: аксіологічно-мотиваційний компонент (усвідомлення необхідності емоційно-ціннісного ставлення до оволодіння іншомовними знаннями, необхідними для професійної діяльності), когнітивний (розвиток спеціалізованих професійних знань, умінь та навичок оволодіння здобувачами вищої освіти англійською мовою спеціального вжитку) та регулятивно-діяльнісний (реалізація практичних навичок, умінь і досвіду прояву іншомовної компетенції в конкретних ситуаціях). На основі результатів наукових досліджень сутність іншомовної компетентності майбутніх фахівців із навігації й управління морськими суднами визначено як особистісну характеристику здобувача, готового на основі засвоєної системи знань, умінь i навичок, сформованих мотивів i цінностей систематично та усвідомлено організовувати професійну діяльність. 


\title{
ESSENCE AND SPECIFICITY OF FOREIGN LANGUAGE COMPETENCE OF FUTURE SPECIALISTS IN NAVIGATION AND SHIP HANDLING AT SEA
}

\author{
Shvetsova I. V. \\ Candidate of Pedagogical Sciences, \\ Associate Professor at the Department of English in Navigation \\ Kherson State Maritime Academy \\ Ushakova str.,20, Kherson, Ukraine \\ orcid.org/0000-0002-6801-5204 \\ isvecova581@gmail.com
}

Key words: foreign language education, professional training of future specialists in navigation and ship handling at sea, professional readiness of future specialists, value attitude to a foreign language.
The article examines the essence and specificity of foreign language competence of future specialists in navigation and ship handling at sea. An analysis of recent publications on the subject has been carried out and features of foreign language competence of future professionals have been identified. It is determined that mastering and using a foreign language in higher education institutions is the formation of foreign language competence, which provides the ability to apply subject, scientific knowledge, tools and activities in professional communication, which increases general competence and contributes to psychological readiness for professional activity. To analyze theoretical and methodological bases of formation of foreign language competence of future specialists in navigation and management of sea vessels and on the basis of the analysis of results of scientific researches use of research concepts is characterized: "competence", "foreign language competence", "professional readiness of future specialists". Based on modern pedagogical approaches and directions, which were analyzed in the study, the following components of foreign language competence of future specialists in navigation and ship handling are identified: axiological-motivational component (awareness of the need for an emotional and moral attitude to acquire other knowledge necessary for professional activity), cognitive (development of specialized professional knowledge, skills and abilities of masters of higher education in English for special purposes) and regulatory activity (implementation of practical skills, abilities and experience of foreign language competence in specific situations). Based on the results of scientific research, the essence of foreign language competence of future specialists in navigation and ship handling at sea is defined as a personal characteristic of the applicant. The main goal of the project is to develop a systematic and systematically organized professional activity on the basis of the acquired system of knowledge, skills and abilities, formed motives and values.
Постановка проблеми. Професійна освіта на грунті соціально-економічного, науково-технічного і загальнокультурного прогресу ставить за мету формування в майбутніх фахівців із навігації та управління суднами здатності оволодіння іноземною мовою як засобом комунікації, набуття професійно-спрямованої діяльності. У Загальноєвропейських рекомендаціях із мовної освіти визначено основні напрями професійної підготовки фахівців, що передбачають досягнення студентами немовних факультетів достатнього рівня іншомовної комунікативної компетентності у професійній сфері спілкування [5]. Оволодіння і використання іноземної мови в закладах вищої освіти полягає у формуванні іншомовної ком- петентності, яка забезпечує здатність до застосування предметних, наукових знань, засобів діяльності у професійному спілкуванні, що дозволяє підвищити загальну компетентність та сприяє формуванню психологічної готовності до специфіки професійної діяльності.

Мета статті - розкрити сутність та охарактеризувати специфіку іншомовної компетенції майбутніх фахівців із навігації та управління суднами.

Виклад основного матеріалу дослідження. Головним завданням вищої освіти України на сучасному етапі визначено підвищення ефективності іншомовної компетентності до професійного спілкування в іншомовному середовищі. Для розуміння суті іншомовної компетентності як складової 
частини професійної підготовки майбутніх фахівців із навігації й управління морськими суднами проаналізовано різні погляди щодо тлумачення поняття «іншомовна освіта» в доробках науковців (Л.В. Вікторова, О.В. Захуцька [1], О.В. Ковтун А.В. [7], О.Я. Тимофєєва [11] та ін.). Так, Л.В. Вікторова, О.В. Захуцька трактують його як цілісний організований процес навчання, виховання і розвитку майбутніх фахівців у межах дисципліни «іноземна мова», що сприяє становленню досвіду творчої діяльності, духовному розвитку особистості та формуванню культури з урахуванням напряму підготовки. Інакше кажучи, іншомовна освіта передбачає навчання і виховання слухачів змістом і засобами іноземної мови, які позитивно впливають на їхнє професійне і культурне збагачення та творчий розвиток [1, с. 174].

Аналізуючи особливості вивчення іноземної мови майбутніми фахівцями в закладах вищої освіти в умовах сучасної євроінтеграції, А.В. Савченко головною метою навчання іноземної мови визначає оволодіння нею як засобом комунікації та опанування професійно спрямованою іншомовною компетентністю майбутніми фахівцями [10, с. 97].

Для аналізу теоретичних і методичних основ формування іншомовної компетентності майбутніх фахівців із навігації й управління морськими суднами та на основі аналізу результатів наукових досліджень встановлено використання понять дослідження: «компетентність», «іншомовна компетентність», «професійна готовності майбутніх фахівців». Зупинимося детальніше на підходах до трактування сутності цих понять.

Цілком поділяємо думки В.Я. Желяскова, який розглядає компетентність як набір компетенцій фахівця, потрібних для виконання діяльності в певній сфері. Для того щоб досягти належного рівня компетентності та кваліфіковано виконувати професійну діяльність, потрібні знання і практичний досвід, що свідчать про наявність набору компетенцій, регульованих стандартами. Компетентність не має чітких лімітованих кордонів, вона спрямована на особисті досягнення людини, що базовані на самоосвіті, критичному мисленні, навичках самостійної роботи, умінні прогнозувати результати й можливі рішення, аналізі причинно-наслідкових зв'язків [4, с. 89]. В.В. Киливник визначає поняття компетентності як значно ширше порівняно 3 поняттями знання, уміння та навички, оскільки воно враховує цілісний напрям особистості: здатність долати труднощі, мотивацію, ціннісні орієнтири, самостійність, стереотипи, творчу ініціативу, цілеспрямованість до мети тощо [6, с. 37]. Поняття «компетентність» визначено як інтегративну якість, що містить у собі такі головні аспекти: готовність до ціле- покладання; готовність до дії; готовність до оцінювання; готовність до рефлексії [6, с. 36].

Натомість у виданні «Національний освітній глосарій: вища освіта» компетентність / компетентності представлено як динамічну комбінацію знань, розуміння, умінь, цінностей, інших особистих якостей, що описують результати навчання за освітньою / навчальною програмою. Компетентності покладені в основу кваліфікації випускника. Компетентність (компетентості) як набуті реалізаційні здатності особи до ефективної діяльності не слід плутати 3 компетенцією (компетенціями) як наданими особі повноваженнями» $[8$, с. 32$]$. Отже, компетентність передбачає уміння вирішувати окремі завдання у професійному виді діяльності.

Доцільно звернутися до сутності поняття «іншомовна компетентність» 3 метою виявлення iii специфіки та визначення структурних компонентів. Цілком погоджуємося із твердженням Д.І. Демченко про те, що іншомовна компетентність представника певної професійної галузі розглядається як якість особистості, яка характеризується продуктивністю іншомовної діяльності (тобто мовленнєвою діяльністю іноземної мови), високим рівнем творчого мислення, який забезпечує декодування іншомовної інформації професійного характеру. Дослідниця характеризує іншомовну компетентність як ту, що включає цілісний комплекс знань у мовній і професійній сферах, умінь застосовувати ці знання у практичній професійній діяльності [3, с. 447]. Згідно із Загальноєвропейськими Рекомендаціями з мовної освіти іншомовна компетентність - «це здатність функціонувати в реальних умовах спілкування, тобто в динамічному обміні інформацією». При цьому робиться акцент на успішності іншомовної комунікації, яка залежить від готовності і бажання комуніканта висловлювати свої думки іноземною мовою, користуватися власним словниковим запасом та граматичними структурами для передачі повідомлення [5, с. 56].

На основі сучасних педагогічних підходів та напрямків нами визначено такі компоненти іншомовної компетентності майбутніх фахівців із навігації й управління морськими суднами: аксіологічно-мотиваційний компонент (усвідомлення необхідності емоційно-ціннісного ставлення до оволодіння іншомовними знаннями, необхідними для професійної діяльності), когнітивний (розвиток спеціалізованих професійних знань, умінь та навичок оволодіння здобувачами вищої освіти англійською мовою спеціального вжитку) та регулятивно-діяльнісний (реалізація практичних навичок, умінь і досвіду прояву іншомовної компетенції в конкретних ситуаціях).

Аксіологічно-мотиваційний компонент система цінностей і мотивів формування і підви- 
щення рівня іншомовної компетентності майбутніх фахівців із навігації. У своїх наукових доробках науковці розглядають мотивацію навчальнопізнавальної діяльності як важливий чинник вдосконалення підготовки здобувачів освіти. 3 урахуванням цього однією 3 актуальних проблем сучасних закладів освіти є побудова такого навчально-виховного процесу, який зможе бути основою для формування та розвитку мотиваційної сфери студентів. До поняття мотивації входить цілий комплекс аспектів, під якими розуміється система спонукань: мотиви, потреби, інтереси, прагнення, цілі, потяги, мотиваційні установки (диспрозії), ідеали. Головною характеристикою мотиваційної сфери є ієрархія мотивів, що дозволяє виявити особистісний зміст діяльності для будь-якої людини. Отже, мотивацією для студента виступає бажання вчитися не тільки заради досягнення академічної мети, але і для професійного росту $[8$, с. 31$]$. Реалізація мотивів оволодіння іншомовними знаннями здійснюється в процесі ціннісної орієнтації, відбиваючи спрямованість особистості здобувача освіти на досягнення визначеної мети професійної підготовки.

Формування ціннісного відношення до іноземної мови як засобу формування іншомовної компетентності, на думку Д.І. Демченко, дозволяє розв'язувати низку професійно значущих завдань: озброювати здобувачів освіти знаннями про те, що вони знають, вже вміють і якими є межі цих умінь відносно використання іноземної мови в майбутній професійній діяльності; виховувати в них бажання займатися самоосвітою; розвивати прагнення відкривати для себе нові можливості іноземної мови в формуванні іншомовної компетентності особистості [3]. Отже, аксіологічно-мотиваційний компонент стимулює прагнення до самореалізації та позитивного ставлення до іноземної мови і можливостей ії використання в процесі виконання професійних функцій.

Когнітивний компонент іншомовної компетентності передбачає володіння мовними знаннями (їхній обсяг і рівень, практичні комунікативні знання). До них відносимо граматичні структури, характерні для ділового стилю і професійної літератури; знання лексики; професійної термінології; міжнародних документів, та ін. Так, у ході формування когнітивного компоненту іншомовної компетентності майбутніх фахівців із навігації і управління морськими суднами можуть бути сформовані навички читання інструкцій та текстів професійного спрямування, сприймання на слух аудіозаписів, розвиток уміння писати особисті та ділові листи, уміння обговорювати процедури завантаження/виваження, процедури зачищення трюмів, обговорювати особливості управління судном, а також висловлюватися щодо правил без- пеки та процедур перевезення небезпечних вантажів, використовуючи SMCP, описувати допоміжні засоби судноводіння: вогні, звукові сигнали, буї. У контексті визначеного компоненту необхідним $\epsilon$ володіння навичками імітування комунікації під час проходження вузькостей, під час перебування судна у системі розділу руху.

Когнітивний компонент іншомовної компетентності майбутніх фахівців із навігації і управління морськими суднами передбачає володіння письмовими уміннями. До таких належить: складання звітів про проведення робіт, пошкодження вантажу, події, що сталися під час морського переходу, опис допоміжних навколишніх засобів у судноводінні, корегування на картах, запис інформації з імітованої телефонної розмови та ін.

Регулятивно-діяльнісний компонент (практичні навички, уміння використовувати мовні знання для вирішення професійних задач і досвід проявляти їх у конкретній ситуації). Цей компонент передбачає здатність і готовність до міжособистісної діяльності: робота в команді (що вимагає навичок міжособистісних стосунків), здатність до спілкування 3 фахівцями 3 інших галузей, здатність працювати в міжнародному середовищі (сприймати культурні відмінності).

Результатом процесу формування іншомовної компетентності здобувачів освіти у ЗВО є формування готовності до володіння такою компетентністю у професійній діяльності, що є показником якості підготовки і перевіряється у практичній професійній діяльності.

Тлумачення поняття готовності до певного виду діяльності розглядають С.В. Гаркуша [2] (професійна готовність студента), M.I. Римарчук (формування професійної готовності в контексті впровадження студентоцентрованого підходу) [9].

Підходи до поняття «готовність» різноманітні, і кожна наука надає цьому поняттю деякі індивідуальні характеристики. С.В. Гаркуша стверджує, що і педагоги, і психологи, і соціологи дають споріднені дефініції. «Ядро цього поняття включає в себе як психологічну готовність, яка являє собою базу та стійку платформу діяльності, так і практичну (професійну) готовність для застосування усіх знань і умінь» [2]. М.I. Римарчук тлумачить професійну готовність як особистісну психологічну якість фахівця, яка $\epsilon$ необхідною умовою та регулятором діяльності людини під час виконання своїх трудових обов'язків [9].

Важливим чинником забезпечення професійної готовності майбутніх фахівців, на думку M.I. Римарчук, $є$ застосування до організації освітнього процесу студентоцентрованого підходу, що суттєво впливає на особистісний розвиток студентів та їхню професійну ідентифікацію. Важливим 
якісним показником такого підходу вважається розширення автономії студентів у виборі навчальних курсів. Завдяки тому, що студентоцентрований підхід передбачає статус студентів як активних учасників їхнього власного навчання, суттєво зростає значення їхньої внутрішньої мотивації до вдосконалення особистісних і професійних якостей, детермінує усвідомлення студентами важливої ролі опанування навчальної програми, психологічних умінь і здатностей як основного знаряддя майбутньої професійної взаємодії, способу фахового самовираження, розв'язання професійних завдань [9].

Погоджуємося 3 думкою Д.І. Демченко, що 3 точки зору вимог до рівня підготовки випускників ЗВО іншомовна компетентність $є$ інтегральною характеристикою якості підготовки здобувача освіти, що пов'язана зі здатністю цільового осмислення застосування комплексу знань, умінь, навичок, ставлень щодо певної професійної діяль- ності і покликана забезпечити комплексне досягнення цілей [3].

Висновки і перспективи подалыших розробок у цьому напрямку. Отже, на основі результатів наукових досліджень сутність іншомовної компетентності майбутніх фахівців із навігації i управління морськими суднами визначаємо як особистісну характеристику здобувача, готового на основі засвоєної системи знань, умінь і навичок, сформованих мотивів і цінностей систематично та усвідомлено організовувати професійну діяльність. Специфіка іншомовної компетенції майбутніх фахівців із навігації та управління суднами полягає у бажанні розширювати професійний світогляд, у готовності здобувача освіти реалізовувати сформовану компетенцію у професійній діяльності та на відповідному рівні володіння іноземною мовою, професійними знаннями використовувати ㄲi в ході професійного спілкування у відповідних ситуаціях.

\section{ЛІТЕРАТУРА}

1. Вікторова Л.В., Захуцька О.В. Система іншомовної підготовки дорослих в умовах глобалізації освіти. Науковий вісник Національного університету біоресурсів і природокористування України. Серія: Філологічні науки. 2017. № 263. С. 165-172.

2. Гаркуша С.В. Поняття та компоненти професійної готовності майбутніх учителів до педагогічної діяльності. Вісник Чернігівського начіонального педагогічного університету. Педагогічні науки. 2013. Вип. 110. С. 198-201.

3. Демченко Д.І. Формування професійної іншомовної компетентності майбутніх юристів засобами іноземної мови у фаховій підготовці: монографія. Харків, 2014. 213 с.

4. Желясков В.Я. Обгрунтування наукових підходів системи підготовки майбутніх судноводіїв до професійної комунікативної взаємодії. Педагогіка формування творчої особистості у вищій $i$ загальноосвітній школах. Запоріжжя, 2018. Вип. 60. С. 53-60.

5. Загальноєвропейські Рекомендації з мовної освіти: вивчення, викладання, оцінювання / за ред. С.Ю. Ніколаєва. Київ : Ленвіт, 2003. 237 с.

6. Киливник В.В. Формування соціокультурної компетентності майбутніх учителів іноземної мови в системі педагогічного коледжу : дис. ...канд. пед. наук : 13.00.04. Вінниця, 2019. 290 с.

7. Ковтун О.В. Технологія формування іншомовної професійної компетентності студентів в освітньому просторі закладу вищої освіти. Науковий вісник Південноукраӥнського національного педагогічного університету імені К.Д. Ушинського. Одеса, 2019. Вип. 3(128). С. 117-125.

8. Національний освітній глосарій: вища освіта / авт.-уклад. : І.І. Бабин, Я.Я. Болюбаш, А.А. Гармаш й ін.; за ред. Д.В. Табачника і В.Г. Кременя. Київ : ТОВ «Видавничий дім «Плеяди», 2011. 100 с.

9. Римарчук М.I. Формування професійної готовності майбутніх лікарів у контексті впровадження студентоцентрованого підходу. Медична освіта. 2019. № 1. C. 32-36. DOI: 10.11603/ me.2414-5998.2019.1.9543.

10. Савченко А.В. Особливості іншомовної освіти у вищих навчальних закладах в умовах сучасної Євроінтеграції. Наукові праиі. Педагогіка. 2018. Вип. 299. T. 311. С. 97-99. URL : https: // lib.chmnu. edu.ua/ pdf/naukpraci/pedagogika/ 2018/ 311-299-20.pdf (дата звернення: 11.07. 2021).

11. Тимофєєва О.Я. Формування соціально-комунікативної компетентності майбутніх судноводіїв у процесі вивчення гуманітарних дисциплі : дис. ...канд. пед. наук : 13.00.04 / Національна академія Державної служби України імені Богдана Хмельницького. Хмельницький, 2018. 273 с.

\section{REFERENCES}

1. Viktorova L. V., Zakhucjka O. V. (2017) Systema inshomovnoji pidghotovky doroslykh v umovakh ghlobalizaciji osvity [Foreighlanguage educationof adults in the context of educational globalization]. Naukovyj visnyk Nacionaljnogho universytetu bioresursiv i pryrodokorystuvannja Ukrajiny. Serija: Filologhichni nauky. no 263. pp. $165-172$. 
2. Gharkusha S. V. (2013) Ponjattja ta komponenty profesijnoji ghotovnosti majbutnikh uchyteliv do pedaghoghichnoji dijaljnosti [Concepts and components of future teachers' professional readiness for pedagogical activity]. Visnyk Chernighivsjkogho nacionaljnogho pedaghoghichnogho universytetu. Pedaghoghichni nauky. vol. 110. pp. 198 - 201.

3. Demchenko D. I. (2014) Formuvannja profesijnoji inshomovnoji kompetentnosti majbutnikh jurystiv zasobamy inozemnoji movy u fakhovij pidghotovci: monoghrafija [Formation of professional foreign language competence of the future lawyer]. Kharkiv. P. 213.

4. Zheliaskov V. Ya. (2018) Obgruntuvannia naukovykh pidkhodiv systemy pidhotovky maibutnikh sudnovodiiv do profesiinoi komunikatyvnoi vzaiemodii [Objectivation of scientific approaches to the system of future maritime personnel training to professional communicative interaction]. // Pedahohika formuvannia tvorchoi osobystosti u vyshchii i zahalnoosvitnii shkolakh : zb. nauk. pr. / redkol.: A.V. Sushchenko (holov. red.) ta in. Zaporizhzhia: KPU, Vol. 60. P. 224. T. 1.

5. Zaghaljnojevropejsjki Rekomendaciji z movnoji osvity: vyvchennja, vykladannja, ocinjuvannja (2003) [Common European Framework of Reference for Language Education: Learning, Teaching, Assessment] / za red. S. Ju. Nikolajeva. - Kyjiv: Lenvit, P. 237.

6. Kylivnik V.V. (2019) Formuvannja sociokuljturnoji kompetentnosti majbutnikh uchyteliv inozemnoji movy v systemi pedaghoghichnogho koledzhu [Formation of Sociocultural Competence of Future Foreign Language Teachers in the College of Pedagogy] (PhDThesis), Vinnytsia: Vinnytsia Mykhailo Kotsiubynsky State Pedagogical University.

7. Kovtun O. V. (2019) Tekhnolohiia formuvannia inshomovnoi profesiinoi kompetentnosti studentiv $\mathrm{v}$ osvitnomu prostori zakladu vyshchoi osvity [Technology of forming students' foreign-language professional competence in the educational space of higher education institution]. Naukovyi visnyk Pivdennoukrainskoho natsionalnoho pedahohichnoho universytetu imeni K. D. Ushynskoho. Odesa. vol. 3 (128). pp. 117-125.

8. Nacionaljnyj osvitnij ghlosarij: vyshha osvita (2011) [National educational glossary: higher education], Kyiv: TOV Vydavnychyj dim Plejady.

9. Rymarchuk M. I. (2019) Formuvannja profesijnoji ghotovnosti majbutnikh likariv u konteksti vprovadzhennja studentocentrovanogho pidkhodu [Formation of professional readiness of future doctors in the context of implementation of the student-centered approach]. Medychna osvita, no 1. pp. $32-36$.

10. Savchenko A. V. (2018) Osoblyvosti inshomovnoi osvity u vyshchykh navchalnykh zakladakh v umovakh suchasnoi Yevrointehratsii [Characteristic of foregn education in the universities in conditions of modern European integration]. Naukovi praci. Pedaghoghika (electronic journal), vol. 299, pp. 97-99 (accessed 11 July 2021.

11. Tymofieieva O. (2018) Formuvannja socialjno-komunikatyvnoji kompetentnosti majbutnikh sudnovodijiv u procesi vyvchennja ghumanitarnykh dyscyplin [Formation of Social Communicative Competence of Future Navigators in the Learning Process of the Liberal Arts] (PhD Thesis), Khmelnytskyi: The National Academy of the State Border Guard Service of Ukraine named after Bohdan Khmelnytskyi. 